\title{
Implementing Regional Sediment Management (RSM): Policy Guidance and Authorities Pertinent to Improving the Use of Dredged Sediments
}

By Matthew H. Schrader

PURPOSE: This Technical Note (TN) provides information on applicable U.S. Army Corps of Engineers (USACE) policy guidance and authorities to assist USACE districts in the implementation of Regional Sediment Management (RSM) and includes methods to better integrate RSM strategies to improve the use of sediments into new and existing projects. This TN is an update to CHETN-XIV-8 Authorities and Policies Supporting Implementation of Regional Sediment Management (Martin 2002a), providing districts up-to-date information and examples to better evaluate and integrate RSM, where justified.

BACKGROUND: RSM is an approach for managing sediments across multiple projects and business lines in order to provide balanced sustainable solutions. Annually, USACE dredges approximately 200,000 million cubic yards of sediment, of which a significant portion is disposed of in deep offshore waters. At the same time, coastal and inland areas that could have benefited from the sediment are drowning and eroding, etc., resulting in reduced resilience of coastal communities. RSM applies a system perspective that includes coastal, estuarine, riverine, and reservoir systems and involves coordinating dredging and other sediment management activities to retain sediments within natural systems, improve the use of sediments, and achieve greater efficiency and benefits through improved coordination and integration across USACE and with partnering organizations, governments, and stakeholders. RSM is accomplished by adhering to the following RSM Operating Principles:

1. Recognize sediments as a regional resource and prioritize their use.

2. Link and leverage across multiple projects, business lines, and authorities.

3. Improve operational efficiencies and natural exchange of sediments.

4. Evaluate and implement economically viable and environmentally sustainable solutions.

5. Consider regional implications of local sediment actions which benefit the region.

6. Enhance technical knowledge and tools for regional approaches.

7. Share lessons learned, information, data, tools and technologies.

8. Communicate and collaborate within the USACE and with stakeholders and partners.

Benefits of applying these principles are improved sediment management, reduced life-cycle costs, increased environmental benefits, enhanced partnerships with stakeholders, and more resilient and sustainable projects and systems (Rosati et al. 2001; Lillycrop et al. 2011).

INTEGRATING RSM STRATEGIES INTO PROJECTS: RSM is most successful when the RSM principles are integrated into projects with forethought and planning to make sediment management actions strategic rather than only actions of opportunity (Martin 2002b). Actions of opportunity require a convergence of several factors: funding, permits, contracting, sponsor 
interest, and USACE willingness. As RSM and USACE projects evolve, such opportunities will arise and should be taken. However, strategic actions are planned with foresight into the funding, permits, contracting, timelines, USACE and sponsor interest, etc., needed to accomplish project goals. The benefits of a strategic approach are that the components are in place to move comprehensive actions forward and take full advantage of all RSM opportunities.

RSM strategies are similar to alternatives in plan formulation and can be integrated into any study or report, Operation and Maintenance (O\&M) action, or new construction project involving sediment. Therefore, an RSM strategy should not be considered a separate project, but an approach or alternative to integrate into existing authorized projects or into projects seeking authorization. This is the most effective way to ensure that the RSM approach will be practiced into the future. The key to using existing or new authorities to implement RSM is to ensure the strategies are fully developed with care given to minimizing cost and capturing all benefits. During the feasibility study process, if the cost for an RSM strategy is greater than the Federal Standard (described later in this Technical Note), the strategy can be implemented if the benefits are reasonable and a non-federal sponsor is willing to either cost share in, or pay $100 \%$ of, the additional costs. No additional authority is needed. After the feasibility phase, Section 204 of the Water Resources Development Act (WRDA) of 1992 (U.S. Congress 1992) can be used to evaluate and implement beneficial uses of dredged material.

Policy Guidance. There is a significant amount of Civil Works (CW) policy guidance that directs USACE to use a systems approach in plan formulation and in implementing projects. While the guidance does not provide districts with the specific authority to implement RSM strategies, a systems approach is inherent in the RSM Principles. A summary of the most relevant guidance is provided in Table 1 and can be cited in post-authorization change reports, feasibility studies, Dredged Material Management Plans (DMMP) and other reports to support incorporation of RSM strategies. Efforts to capture all benefits and costs of RSM strategies are essential to their equitable comparison with other alternatives.

Capture All Benefits of an RSM Strategy. An RSM strategy often achieves benefits beyond a single project's boundaries and/or mission area; therefore, it is essential that all benefits are captured for a project as well as other federal and non-federal projects within the region that benefit from the strategy. In some cases, the RSM strategy will have higher initial costs than other alternatives. Districts often capture the initial cost to the project but fail to capture benefits within the project area or elsewhere in the region. These could include benefits that are not monetized (e.g., some environmental or social benefits) as well as those that are, such as costs avoided to another USACE business line or project, a non-federal project, or elsewhere in the region. Examples of such benefits include the following:

- Reduced number of dredge mobilizations

- Conserved volume of sand sources

- Conserved capacity of placement areas

- Maintenance of low priority channels

- Advanced maintenance of navigation channels

- Sand provided to non-federal coastal storm risk management projects

- Coastal or wetland habitat created or maintained

- Avoiding life-cycle costs of upland or offshore placement, such as purchasing land, permitting, and maintenance. 


\begin{tabular}{|c|c|c|}
\hline Name & Summary & Overview \\
\hline $\begin{array}{l}\text { Appendix E of } \\
\text { Engineer } \\
\text { Regulation } \\
\text { (ER) 1105-2- } \\
100 \\
\text { (USACE } \\
2000 a)\end{array}$ & $\begin{array}{l}\text { Acknowledges the } \\
\text { need for systems } \\
\text { analysis in shoreline } \\
\text { studies }\end{array}$ & $\begin{array}{l}\text { A systems analysis is included among the principles in guidance for } \\
\text { evaluation of benefits from Coastal Storm Risk Management projects. } \\
\text { Paragraph E-24(f) includes requirements for a systems analysis approach, } \\
\text { which includes physical processes, coastal alterations, shoreline change } \\
\text { forecasts, and economic benefits and costs. }\end{array}$ \\
\hline $\begin{array}{l}\text { Appendix E of } \\
\text { ER 1105-2-100 } \\
\text { (USACE } \\
\text { 2000a) }\end{array}$ & $\begin{array}{l}\text { Consideration of the } \\
\text { broader landscape } \\
\text { implications of } \\
\text { navigation } \\
\text { improvements. }\end{array}$ & $\begin{array}{l}\text { Includes requirements of Section } 5 \text { of the River \& Harbor Act of } 1935 \text {; } \\
\text { each investigation on navigation improvements potentially affecting } \\
\text { adjacent shorelines will include analysis of probable effects on shoreline } \\
\text { configurations. A distance of not less than } 10 \text { miles on either side of the } \\
\text { improvement should be analyzed. (ER 1105-2-100, E-14(b)). }\end{array}$ \\
\hline $\begin{array}{l}\text { Appendix F of } \\
\text { ER 1105-2-100 } \\
\text { (USACE } \\
2000 \mathrm{~b})\end{array}$ & $\begin{array}{l}\text { Continuing } \\
\text { Authorities Program } \\
\text { (CAP) }\end{array}$ & $\begin{array}{l}\text { Provides planning guidance related to the CAP including guidance on how } \\
\text { CAP authorities can be combined for comprehensive planning. For } \\
\text { instance, Section } 111 \text { projects that address shore damage prevention or } \\
\text { mitigation caused by federal navigation projects: "Proposed } \\
\text { implementation measures shall be coordinated with other non-Federal shore } \\
\text { protection projects in the same geographic region; To the extent } \\
\text { practicable, any Section } 111 \text { projects and shore protection pursued under } \\
\text { other authorities in the same area will be combined into a comprehensive } \\
\text { regional project." (ER } 1105-2-100, \text { F-26.c(2)). Additionally, paragraph F- } \\
18 \text { covers multi-purpose CAP projects, noting that Section } 204 \text { (Beneficial } \\
\text { Use of Dredged Material) can be used in conjunction with Section } 107 \\
\text { (Navigation Improvements) (F-8.c). }\end{array}$ \\
\hline $\begin{array}{l}\text { Engineer } \\
\text { Manual (EM) } \\
1110-2-5026 \\
\text { (USACE 1987) }\end{array}$ & $\begin{array}{l}\text { Beneficial uses of } \\
\text { dredged material }\end{array}$ & $\begin{array}{l}\text { Provides guidance for planning, designing, developing, and managing } \\
\text { dredged material for beneficial uses, incorporating ecological concepts and } \\
\text { engineering designs with biological, economical, and social feasibility. } \\
\text { Defines beneficial use as using dredged sediments as a resource in a } \\
\text { productive way, providing environmental, economic, or social benefits. }\end{array}$ \\
\hline $\begin{array}{l}\text { ER 1130-2-520 } \\
\text { (USACE 1996) }\end{array}$ & $\begin{array}{l}\text { Navigation and } \\
\text { Dredging Operations } \\
\text { and Maintenance } \\
\text { Policies }\end{array}$ & $\begin{array}{l}\text { Chapter } 8 \text { covers USACE policy on dredging. Paragraph } 8-2 \text { states } \\
\text { "Dredging shall be accomplished in an efficient, cost-effective, and } \\
\text { environmentally acceptable manner..." (8-2.a) and then states "The } \\
\text { maximum practicable benefits will be obtained from materials dredged } \\
\text { from authorized Federal navigation projects, after taking into consideration } \\
\text { economics, engineering, and environmental requirements in accordance } \\
\text { with applicable Federal laws and regulations }(8-2 . a(1)) . " \text { This policy } \\
\text { mentions economics as well as engineering and environmental } \\
\text { considerations. These considerations are relevant to the Federal Standard, } \\
\text { particularly that cost is not the only consideration given under the Federal } \\
\text { Standard in the Code of Federal Regulations (CFR 2012a, b, c, d)(33 CFR } \\
\text { Parts 335-338, respectively). }\end{array}$ \\
\hline $\begin{array}{l}\text { Environmental } \\
\text { Operating } \\
\text { Principles } \\
\text { (USACE 2012) }\end{array}$ & $\begin{array}{l}\text { Studies must } \\
\text { document how plans } \\
\text { are consistent with } \\
\text { each of the USACE } \\
\text { Environmental } \\
\text { Operating Principles. }\end{array}$ & $\begin{array}{l}\text { The Environmental Operating Principles (EOPs) were developed to ensure } \\
\text { that USACE missions include totally integrated sustainable environmental } \\
\text { practices. The EOPs provide corporate direction to ensure the workforce } \\
\text { recognizes the USACE role in, and responsibility for, sustainable use, } \\
\text { stewardship, and restoration of natural resources across the Nation and, } \\
\text { through the international reach of its support missions. The Institute for } \\
\text { Water Resources (IWR) Report 02-PS-2 (Martin 2002b) notes "These } \\
\text { principles emphasize contributing to sustainability, and improved business } \\
\text { practices, and RSM helps support sustainability and improved project and } \\
\text { program integration." The IWR report provides additional detail on how } \\
\text { RSM supports the principles, and any study recommending a RSM strategy } \\
\text { should emphasize this. }\end{array}$ \\
\hline
\end{tabular}


Benefits of an RSM strategy can also be based on the principle that sediment is a valuable resource and should be maintained in the active sediment system. For example, if dredged material suitable for placement on a beach, nearshore environment, or other beneficial use is disposed in an Ocean Dredged Material Disposal Site, it is often not technically feasible to recover the material in the future (either naturally or through dredging), and the value of the material is lost to the system. The following examples demonstrate benefits, including costs avoided, of RSM strategies applied under several USACE mission areas.

Example 1 - Coastal storm risk management and coastal navigation. A Coastal Storm Risk Management (CSRM) feasibility study is planning to use a federal navigation inlet as a sand source, which will maintain the inlet's authorized depth. Assuming that scheduling of the CSRM project construction can coincide with the navigation project's inlet maintenance and that both projects can use the same type of dredge, only one dredge mobilization will be required instead of two to complete both projects, thus reducing the overall cost. This should be reported as a cost avoided by the RSM strategy.

Example 2 - Inland navigation and ecosystem restoration. Sediment is trapped behind a structure that is part of an authorized inland navigation project. The district would like to bypass the sediment to improve the structure's effectiveness. In addition to project benefits and costs, the district should quantify the benefits and costs to downstream systems or projects from the bypassed sediment, which could differ depending on the bypass method used (e.g., flushing a large amount of sediment vs. other methods to bypass small amounts of sediment). Benefits could be captured under a number of categories (i.e., ecosystem value). Note that the RSM strategy could have added impacts, such as ecological changes from an increased sediment load, which also must be considered. Typically, ecosystem benefits are quantified in habitat units or qualitative terms. There are ongoing efforts to quantify ecosystem goods and services by several federal agencies, including USACE, which allow for value to be expressed in ways other than dollars.

\section{Capture and Compare All Costs of an RSM Strategy to Life-Cycle Costs of} Alternatives. Considerations involving costs, such as the Federal Standard, are often viewed as obstacles to implementing RSM strategies. The Federal Standard is defined in 33 Code of Federal Regulations (CFR 2012), Part 335, Section 335.7 - Definitions, which states "Federal Standard means the dredged material disposal alternative or alternatives identified by USACE which represent the least costly alternatives consistent with sound engineering practices and meeting the environmental standards established by the 404(b)(1) evaluation process or ocean dumping criteria."

The Federal Standard does not preclude RSM. It is the responsibility of USACE districts to ensure that the life-cycle costs associated with dredging, disposal or placement, and the management of dredged material are captured so that potential RSM strategies are more accurately compared to other alternatives consistent with sound engineering practices and meeting the environmental standards established by the 404(b)(1) evaluation process or ocean dumping criteria. By doing so, an RSM strategy could be identified as the Federal Standard. ER 1110-2-8159 (USACE 1997) states that life-cycle costs include the initial project investment and costs for operation, maintenance, repair, rehabilitation, and replacement. Examples of life-cycle costs that could be included in evaluation of a dredged material placement alternative include 
permitting and sediment testing periodically needed in future years, maintenance or expansion of disposal areas, and required cultural or environmental surveys.

A Headquarters, USACE (HQUSACE) memorandum "Federal Standard Clarification Regarding Federal Dredging Mission and Interactions with Non-Federal Agencies" (USACE 2015) released in October 2015 provides clarification on the proper interpretation and implementation of 33 CFR Parts 335 through 338, which focuses on regulations relating to the Federal Standard and federal maintenance dredging for federal navigation channels.

The following applies the life-cycle cost concept to the previous examples:

Example 1 - Coastal storm risk management and navigation. There are a number of additional and incidental costs if the CSRM project does not use the navigation inlet as a sand source. Rather than one dredge mobilization, two mobilizations may be required to implement both projects. The sand dredged for navigation purposes would be disposed of offshore, upland, or at another site, which could require development, design, and permitting in addition to the design and permitting of the CSRM project.

Example 2 - Inland navigation and ecosystem restoration. Often, dredging accumulated sediment upstream of a structure and returning it downstream of the structure (bypassing) is not accomplished due to cost. However, the impacts and costs downstream resulting from lack of bypassing sediment are not considered or captured. Habitat restoration efforts, stream bank erosion, and other challenges incurred due to blocked sediment transport should be captured in order to understand the life-cycle cost of not implementing RSM.

Reducing the Cost of RSM Strategies. In addition to ensuring the costs of RSM strategies are compared to the full life-cycle costs of other alternatives, it is important to make every effort to reduce the cost of the RSM strategy. Two means for reducing costs are Value Engineering (VE) and industry days.

RSM considerations and strategies should be evaluated in VE efforts to minimize costs. Often, RSM strategies are discussed late in the process making them unviable alternatives. An RSMspecific VE effort could be conducted early in the study process to focus solely on RSM strategies. Industry, stakeholders, and agencies can provide useful input to reduce costs and identify benefits of an RSM strategy. The dredging industry, for instance, can provide innovative cost-reducing methods to beneficially use dredge material. An industry day meeting with knowledgeable dredging industry representatives, stakeholders, and agencies can provide valuable information to support RSM strategies.

DMMPs. DMMPs are required for all federal navigation projects, or groups of inter-related harbor projects, or systems of inland waterway projects (ER 1105-2-100, E-15.a(2)) (USACE 2000a) to ensure there is sufficient dredged material disposal capacity for a minimum of 20 years. ER 1105-2-100 Appendix E (USACE 2000a) states "It is the policy of USACE that all dredged material management studies include an assessment of potential beneficial uses for environmental purposes including fish and wildlife habitat creation, ecosystem restoration and enhancement and/or hurricane and storm damage reduction. Districts and Major Subordinate Commands (MSCs) will make every effort to ensure that sponsors and other interests understand the valuable contributions that beneficial uses can make to management plans and will maximize 
use of regional forums to share experiences of opportunities for beneficial uses" (ER 1105-2100, E.15.a(1)(d)) (USACE 2000a).

Martin (2002b) provides details on DMMP policy and incorporation of RSM including the following: DMMPs are to be updated periodically to identify any potentially changed conditions. DMMPs may address multiple projects, and the development of these plans in the context of RSM may contribute to increased efficiencies and reduced O\&M costs, and a broader array of benefits.

\section{PROJECT AUTHORITIES}

Multiple Purpose Project Authorities. Multiple purpose authorities provide the ability to examine more than one type of water resources problem or opportunity and recommend projects with more than one purpose. USACE mission areas can be combined to address multiple objectives within the localized study area. An RSM strategy can be particularly useful for such a project. Paragraph 3-1 of ER 1105-2-100 (USACE 2000c) states "Within the larger Federal interest in water resource development, the Corps of Engineers is authorized to carry out projects in seven mission areas: navigation, flood damage reduction, ecosystem restoration, hurricane and storm damage reduction, water supply, hydroelectric power generation and recreation... Wherever possible and subject to budgetary policy, projects shall combine these purposes to formulate multiple purpose projects. For example, flood damage reduction projects could include ecosystem restoration and recreation; navigation projects could include hydroelectric power generation and ecosystem restoration."

Funding and approval. Appendix E of ER 1105-2-100 (USACE 2000a) provides additional detail on multiple purpose planning including cost sharing and cost allocation of such projects. Similar to single purpose planning studies, the approval authority depends on the type of report. The authorizing language for a study must allow for multiple purposes. Often, authorizing language will state "... and other related purposes,” or, “... and allied purposes.”

Section 204 CAP. If a project is beyond its feasibility phase and the cost of an RSM strategy is greater than the Federal Standard, Section 204 of the CAP can be used to evaluate and pay for the incremental cost above the base plan, if justified. This section includes input from districts, MSCs, and HQUSACE to provide a comprehensive perspective. Early coordination with a district's vertical team is the best way to address questions regarding policy interpretation and direct the district's path forward with regard to Section 204.

Funding and approval. Currently, $100 \%$ of the feasibility study cost is federal. The nonfederal cost share for implementation is determined as provided in subsections (a) through (d) of Section 103 of WRDA 1986 (U.S. Congress 1986), as amended (Section 2213, U.S. Code [2006, rev. 2011]). There is a federal cost limit of $\$ 10,000,000$ per project. Approval authority is typically at the MSC level. However, if the model Project Partnership Agreement (PPA) (revised June 2016) cannot be applied, approval authority would likely advance to HQUSACE.

Initiating a Section 204 CAP project. The following key factors are necessary for a successful Section 204 CAP project: 
1. Have a Sponsor with a Problem: A Section 204 CAP project cannot be initiated by a USACE district wanting to beneficially use dredged material. A sponsor must identify a well-defined problem requiring USACE assistance. The CAP program will not fund studies seeking to beneficially use dredged material (RSM plans with no well-defined problem to address). A Section 204 CAP project is not a study to determine if a federal project has material that can be beneficially used.

2. A sediment source must be identified from a federal water resources project or a non-federal source $^{1}$; however, if the sediment source is a federal project, it must be authorized, and the material may be from initial construction or from O\&M of the project. A Section 204 CAP study could be completed between authorization and initial construction in the case of using sediment obtained through, or used in, the initial construction of an authorized project.

Alternative formulation under Section 204 CAP. Although the title of the authority contains "beneficial use of dredged material," beneficial use is not the goal of a Section 204 CAP project. The objective is to address a problem as defined by the sponsor. In this sense, it is more straightforward to think of the goal of the authority in the words of Paragraph (a)(3) of Section 204, as amended:

(A) to reduce storm damage to property;

(B) to protect, restore, and create aquatic and ecologically related habitats, including wetlands; and

(C) to transport and place suitable sediment for the purposes of improving environmental conditions in marsh and littoral systems, stabilizing stream channels, enhancing shorelines, and supporting state and local risk management adaptation strategies. (U.S. Congress 1992)

The CAP feasibility study process follows formulation as outlined in ER 1105-2-100 (USACE 2000c), and a Section 204 CAP study should focus on a USACE business line (e.g., Environmental Restoration or Coastal Storm Risk Management). Beneficial use of dredged material may be an alternative, or part of an alternative, recommended by a district to address one of these purposes.

If a Section 204 CAP feasibility study recommends an alternative that uses dredged material in conjunction with other methods (e.g., hard structures) to address a problem, the Section 204 CAP total project costs will include the additional cost (above the least-cost disposal option) for the beneficial use and the cost of the hard structures needed to fully address the problem. However, beneficial use of dredged material should make up a relevant portion of the 204 project cost. There is currently no definition of what a relevant portion should be. Appendix E of ER 1105-2100 (USACE 2000a) provides policy and planning guidance for each CW mission of USACE. Appendix F of ER 1105-2-100 (USACE 2000b) provides general program principles, policies and planning guidance for the nine legislative authorities under the CAP, including Section 204.

\footnotetext{
1 Section 1122 of the Water Infrastructure Improvements for the Nation (WIIN) Act (U.S. Congress 2016) amends Section 204 to state that, " $(a)(1)(B)$...For purposes of projects carried out under this section, the Secretary may include sediment from other Federal sources and non-Federal sources, subject to the requirement that any sediment obtained from a non-Federal source shall not be obtained at Federal expense."
} 
Using the model PPA keeps the majority of coordination at the MSC level and maintains MSC approval authority. See the model PPA for description of when it can be applied. A key point is that one-time placement of dredged material, which provides only temporary benefits, cannot use the current model PPA.

Section 204(d) Projects. Recent guidance uses the term "204(d) projects" to describe a beneficial use project which covers one-time or periodic placement of dredged material. Refer to guidance released on 16 February 2018 (USACE 2018) for additional information (SUBJECT: Implementation Guidance for Regional Sediment Management - Section 204 of the WRDA of 1992, as amended by Section 1038(2) of the Water Resources Reform and Development Act of 2014 (WRRDA 2014 [U.S. Congress 2014]) and Section 1122(i)(2) of WRDA 2016 [Note: WRDA 2016 is included in WIIN Act of 2016], U.S. Congress (2016)).

Section 204(d) projects generally follow the same guidelines described above for traditional Section 204 projects with several key differences.

Key components. Key components of a Section 204(d) project include the following:

- Placement under Section 204(d) may include a single or periodic application of sediment for beneficial use and shall not require operation and maintenance.

- Placement of dredged material under the authority of section 204(d) will primarily be on a one-time basis only. However, multiple placements may be considered for the same site over several years but would need to be justified each time. They would not be considered continuing construction.

- Multiple placements for disposal of material at a single site will be subject cumulatively to the CAP per project federal participation limit of $\$ 10,000,000$.

- Only placement of dredged material may be accomplished under 204(d). The shaping of the dredged material may be incorporated, as reasonably necessary, to achieve placement benefits. 204(d) projects do not include cost sharing in the cost of structures or other components as would be done for traditional Section 204 projects.

- Section 204(d) efforts should only focus on the chosen beneficial use of dredged material. It should not include evaluation of all applicable alternatives as would be expected under a traditional Section 204 study.

- The effort does not identify a national economic development or national ecosystem restoration plan. It only needs to show that the beneficial use is justified.

- Documentation and approval of placements under Section 204(d) will generally follow the same guidelines in ER 1105-2-100, Appendix F that traditional Section 204 studies follow, including milestones, but the degree of documentation may be much more limited.

- A memorandum of agreement rather than the Section 204 model PPA may be used for Section 204(d) projects. A model memorandum of agreement may be developed for section 204(d) placements and published on the USACE website.

Funding and approval. Placement of material under Section 204(d) is considered a separate activity within the Section 204 CAP, and expenditures will count against the Section 204 programmatic limit, currently $\$ 10,000,000$ Federal. The increment of costs to achieve project 
benefits are shared on a $65 \%$ federal and 35\% non-federal basis, per Section 2017 of WRDA 2007 (U.S. Congress 2007).

Decision-making criteria and approval are described in the 2018 implementation guidance. Project approval and the determination that benefits of the recommended placement justify the incremental costs are likely delegated from the ASA-CW to the MSC.

SUMMARY: This Technical Note (TN) provides an update to CHETN-XIV-8 Authorities and Policies Supporting Implementation of Regional Sediment Management (Martin 2002a) and provides information on applicable USACE policy guidance and authorities to assist USACE districts in the implementation of Regional Sediment Management (RSM). Methods to utilize existing policy and authorities to better evaluate and integrate RSM strategies to improve the use of sediments into new and existing projects are discussed.

ADDITIONAL INFORMATION: This Regional Sediment Management Technical Note (RSMTN) was prepared by Matthew Schrader, RSM Center, U.S. Army Engineer District, Jacksonville (SAJ). Funding for this document was provided by the USACE National Regional Sediment Management (RSM) Program, a Navigation Research, Development, and Technology (RD\&T) portfolio program. Additional information pertaining to the National RSM Program may be found at http://rsm.usace.army.mil. Questions regarding this RSM-TN may be addressed to Matthew Schrader, Matthew.H.Schrader@usace.army.mil. Questions pertaining to the RSM Program may be addressed to the USACE National RSM Program Manager, Katherine Brutsche, Katherine.E.Brutsche@usace.army.mil.

This ERDC Regional Sediment Management Technical Note (RSM-TN) should be cited as follows:

Schrader, M. 2019. Implementing Regional Sediment Management (RSM): Policy Guidance and Authorities Pertinent to Improving the Use of Dredged Sediments. ERDC/TN RSM-19-1. Vicksburg, MS: U.S. Army Engineer Research and Development Center. http://dx.doi.org/10.21079/11681/32383

\section{REFERENCES}

Code of Federal Regulations (CFR). 2012a. 33 CFR 335: Title 33 - Navigation and Navigable Waters; Chapter 11 Corps of Engineers, Department of the Army, Department of Defense; Part 335: Operation and Maintenance of U.S. Army Corps of Engineers Civil Works Projects Involving the Discharge of Dredged or Fill Material into Waters of the U.S. or Ocean Waters. Washington, DC: National Archives and Records Administration, Office of the Federal Register.

Code of Federal Regulations (CFR). 2012b. 33 CFR 336: Title 33 - Navigation and Navigable Waters; Chapter 11 - Corps of Engineers, Department of the Army, Department of Defense; Part 336: Factors to be Considered in the Evaluation of Army Corps of Engineers Dredging Projects Involving the Discharge of Dredged Material into Waters off the U.S. and Ocean Waters. Washington, DC: National Archives and Records Administration, Office of the Federal Register.

Code of Federal Regulations (CFR). 2012c. 33 CFR 337: Title 33 - Navigation and Navigable Waters; Chapter 11 Corps of Engineers, Department of Defense; Part 337: Practice and Procedures. Washington, DC: National Archives and Records Administration, Office of the Federal Register. 
Code of Federal Regulations (CFR). 2012d. 33 CFR 338: Title 33 - Navigation and Navigable Waters; Chapter IICorps of Engineers, Department of Defense; Part 338: Other Corps Activities Involving the Discharge of Dredged Material or Fill into Waters of the U.S. Washington, DC: National Archives and Records Administration, Office of the Federal Register.

Lillycrop, L. S., J. W. McCormick, L. E. Parson, and M. A. Chasten. 2011. Adaptive management through regional sediment management. Proceedings of the Western Dredging Association (WEDA XXXI) Technical Conference and Texas A\&M University (TAMU 42) Dredging Seminar, 2,061-2,074. Nashville, TN.

Martin, L. R. 2002a. Authorities and Policies Supporting Implementation of Regional Sediment Management. ERDC/CHL CHETN-XIV-8. Vicksburg, MS: U.S. Army Engineer Research and Development Center. http://hdl.handle.net/11681/4980

Martin, L. R. 2002b. Regional Sediment Management: Background and Overview of Initial Implementation. IWR Report 02-PS-2. Prepared as part of the U.S. Army Corps of Engineers Institute for Water Resources Policy Studies Program. Fort Belvoir, VA: USACE Institute for Water Resources. https://www.bing.com/search?q=Martin\%20\%22Regional\%20Sediment $\% 20$ Management\&cbir=sbi\&imageBin $=\& q s=$ n\&form $=\mathrm{QBRE} \& \mathrm{sp}=1 \& \mathrm{pq}=$ martin $\% 20 \% 22$ regional $\% 20$ sediment $\% 20$ management $\& \mathrm{sc}=1$ 36\&sk=\&cvid=31AACBE18BBB472E8664C37BDA2F444A

Rosati, J. D., B. D. Carlson, J. E. Davis, and T. D. Smith. 2001 (rev. 2004). The Corps of Engineers National Regional Sediment Management Demonstration Program. ERDC/CHL CHETN-XIV-1. Vicksburg, MS: U.S. Army Engineer Research and Development Center. http://hdl.handle.net/11681/5014

U.S. Army Corps of Engineers (USACE). 1987. Engineering and Design: Beneficial Uses of Dredged Materials. EM 1110-2-5026. Washington, DC: U.S. Army Corps of Engineers.

. 1996. Project Operations: Navigation and Dredging Operations and Maintenance Policies. ER 1130-2-520. Washington, DC: U.S. Army Corps of Engineers.

1997. Engineering and Design: Life Cycle Design and Performance. ER 1110-2-8159. Washington, DC: U.S. Army Corps of Engineers.

. 2000a. Planning: Planning Guidance Notebook; Appendix E, Civil Works Missions and Evaluation Procedures. ER 1105-2-100. Washington, DC: U.S. Army Corps of Engineers.

. 2000b. Planning: Planning Guidance Notebook; Appendix F, Continuing Authorities Program. ER 1105-2100. Washington, DC: U.S. Army Corps of Engineers.

. 2000c. Planning: Planning Guidance Notebook. ER 1105-2-100. Washington, DC: U.S. Army Corps of Engineers.

2012. USACE 'reinvigorates' Environmental Operating Principles. Washington, DC: U.S. Army Corps of Engineers. $\quad$ https://www.usace.army.mil/Media/News-Archive/Story-Article-View/Article/477944/usacereinvigorates-environmental-operating-principles/

2015. Memorandum for See Distribution: Subject: Federal Standard Clarification Regarding Federal Dredging Mission and Interactions with Non-Federal Agencies. Washington, DC: U.S. Army Corps of Engineers.

2018. Memorandum for See Distribution: Subject; Implementation Guidance for Section 1038(2) of the Water Resources Reform and Development Act of 2014 WRRDA 2014), Integrating Section 1122(i) of the Water Resources Development Act of 2016, Reduction of Federal Cost for Hurricane and Storm Damage Reduction Projects. Washington, DC: U.S. Army Corps of Engineers.

U.S. Code. 2006 (rev. 2011). 33 U.S.C. 2213: Supplement 4; Title 33 - Navigation and Navigable Waters; Chapter 36 - Water Resources Development; Subchapter 1 - Cost Sharing; Section 2213 - Flood Control and Other Purposes. Washington, DC: Office of the Law Revision, Counsel of the U.S. House of Representatives.

U.S. Congress. 1986. Water Resources Development Act of 1986. Public Law No. 99-662 (11/17/1986). House Bill 6. Washington, DC: 99th Congress of the United States.

1992. Water Resources Development Act of 1992. Public Law No. 102-580 (10/31/992). House Bill 6167. Washington, DC: $102^{\text {nd }}$ Congress of the United States. 
2007. Water Resources Development Act of 2007. Public Law No. 110-114 (11/3/2007). House Bill 1495. Washington, DC: 110th Congress of the United States.

2014. Water Resources Reform and Development Act of 2014. Public Law No. 113-121 (10/6/2014). House Bill 3080. Washington, DC: $113^{\text {th }}$ Congress of the United States.

. 2016. Water Infrastructure Improvements for the Nation (WIIN) Act. Public Law No. 114-322 (12/16/2016). Senate Bill 612. Washington, DC: 114th Congress of the United States.

NOTE: The contents of this technical note are not to be used for advertising, publication, or promotional purposes. Citation of trade names does not constitute an official endorsement or approval of the use of such products. 